\title{
Neurobiological Aspects of Depressive Disorder and Antidepressant Treatment: Role of Glia
}

\author{
M. PÁV ${ }^{1}$, H. KOVÁŘ ${ }^{1}$, A. FIŠEROVÁ ${ }^{2}$ E. HAVRDOVÁ ${ }^{1}$, V. LISÁ ${ }^{3}$ \\ ${ }^{1}$ Department of Psychiatry, First Faculty of Medicine, Charles University, Prague, ${ }^{2}$ Institute of \\ Microbiology, Academy of Sciences CR, Prague and ${ }^{3}$ Institute of Physiology, Academy of Sciences \\ CR, Prague, Czech Republic
}

Received March 30, 2006

Accepted February 22, 2007

On-line available April 25, 2007

\section{Summary}

Depression is a complex disorder related to chronic inflammatory processes, chronic stress changes and a hippocampal response. There is a increasing knowledge about the role of glial cells in nutrient supply to neurons, maintenance of synaptic contacts and tissue homeostasis within the CNS. Glial cells, viewed in the past as passive elements with a limited influence on neuronal function, are becoming recognized as active partners of neurons and are starting to be discussed as a possible therapeutic target. Their role in the pathogenesis of depressive disorders is also being reconsidered. Attention is devoted to studies of the different types of antidepressants and their effects on transmembrane signaling, including levels of $\alpha$ subunits of $G$ proteins in $\mathrm{C} 6$ glioma cells in vitro as a model of postsynaptic changes in vivo. These models indicate similarities in antidepressant effects on $\mathrm{G}$ proteins of brain cells and effector cells of natural immunity, natural killers and granulocytes. Thus, an antidepressant response can exhibit certain common characteristics in functionally different systems which also participate in disease pathogenesis. There are, however, differences in the astrocyte G-protein responses to antidepressant treatment, indicating that antidepressants differ in their effect on glial signalization. Today mainstream approach to neurobiological basis of depressive disorders and other mood illnesses is linked to abnormalities in transmembrane signal transduction via G-protein coupled receptors. Intracellular signalization cascade modulation results in the activation of transcription factors with subsequent increased production of a wide array of products including growth factors and to changes in cellular activity and reactivity.

\section{Key words}

Major depression - Mood disorder - Antidepressant - Stress • Hippocampus - Neurogenesis - Astrocyte • C6 glioma cells • Immune system • Natural killer cells $\bullet$ Guanine-binding proteins $\bullet$ $\mathrm{G}$ proteins $\bullet$ Cell signal transduction

\section{Corresponding author}

M. Páv, Clinic of Psychiatry, First Faculty of Medicine, Charles University, Ke Karlovu 11, 12808 Prague 2, Czech Republic. E-mail: pavm@post.cz

\section{Depression as a systemic disorder}

Depression is one of the most prevalent mental disorders and one of leading causes of morbidity, mortality and economic burden worldwide. During four decades of research, biochemical research of depression has focused on the monoamine neurotransmitters and their receptors, in the past decade on receptor transduction mechanisms and intracellular signalization cascades (Avissar and Schreiber 2002, 2006). The family of G- proteins is a crucial convergence point in the signal transduction from many extracellular primary messengers to the intracellular second messengers and cell response (Kovářů and Kovářu 2005). G-protein measurement is applied as one of state markers of depressive patients or subjects under antidepressant, lithium or electroconvulsive treatment (Avissar and Schreiber 2002, 2006). Besides biochemical research, many other approaches contributed significantly to the understanding of 
depression, one of the most fruitful contributions to this comprehension came from the field of psychoneuroimmunology and neuroimmunology (Haddad et al. 2002, Tafet and Bernardini 2003, Schiepers et al. 2005, Havrdová 2005).

Considerable evidence points to some similarities between depression and an inflammatory response (Leonard 2006). So-called "sickness behavior" which is phenomenologically similar to depression with fatigue, anhedonia, loss of energy and anorexia as the prominent features is linked to increased levels of proinflammatory cytokines such as IL-1, IL-6 or TNF $\alpha$ on the periphery, or within CNS (Kelley et al. 2003, Schiepers et al. 2005). Main producers of cytokins on the periphery are activated macrophages and T- and B-cells, in the CNS the activated microglial cells (Hauwel et al. 2005, Shiepers et al. 2005). Chronic inflammatory diseases, e.g. rheumatoid arthritis, are often accompanied by depression (Covic et al. 2006). Some of the immune system cells, e.g. granulocytes or natural killers, show during the course of depression and antidepressant treatment responses in many ways similar to the brain cells. Antidepressants affect cytokine production, promoting anti-inflammatory cytokine phenotype in human blood (Kovářù et al. 1997, Fišerová et al. 2002, Diamond et al. 2006).

Despite progressive understanding of systemic aspects of the depressive disorder, majority of authors are still considering depression as a primarily "brain disorder". There is growing knowledge on the role of glial cells in neurogenesis, neuronal development and maturation, nutrient supply, involvement in the communication at the synaptic contacts and tissue homeostasis and even active participation in the signalization processes (Araque et al. 1999, Laming et al. 2000, Hertz and Zielke 2004). Astrocytes are becoming recognized as active partners of neurons and there are several neuropsychiatric disorders where the role of astrocytes is recognized, e.g. Alzheimer's disease, multiple sclerosis, HIV dementia or dementia with Lewy bodies.

The aim of this paper is to review astrocyte neurobiology associated with depression and antidepressant treatment within the frame of the systemic concept of depression. We will try to show astrocytes as a cell population, which can contribute to the depression development and is affecting neuronal functioning during the disease course. We will focus on the G-protein astrocytic signaling, in respect to the crucial role of $\mathrm{G}$ - proteins in the cell signal transduction. Antidepressant treatment is considered to exert its effect mainly on the neuronal population, we will try to demonstrate that astrocytes can already be regarded as one of the targets of antidepressant treatment which mediate a part of the beneficial effects.

\section{Depression as a stress-induced selective neurodegeneration}

Major depression involves disturbances in emotional, cognitive, immune, autonomic and endocrine functions (Nestler et al. 2002). Nervous, endocrine and immune systems share neurotransmitters, peptide hormones and cytokines as well as their receptors as a common chemical language to communicate with each other (Haddad et al. 2002, Fišerová et al. 2002, Tafet and Bernardini 2003, Kovářù and Kovářu 2005). This interplay is especially important during a stress response. Indeed stressful life events are often precipitating factors for the depression onset (Hayley et al. 2005, Sekot et al. 2005). Neurotransmitters alterations can affect functioning of these systems in many ways, for decades the depression has been linked particularly to disturbances in serotonergic and noradrenergic neurotransmission. Dysfunction in the neurotransmitter systems results, besides psychological and behavioral consequences, in the systemic effect with hyperactivation of stress hypothalamic-pituitary-adrenal axis (HPA) (Haddad et al. 2002, Tafet and Bernardini 2003). The resulting prolonged hypercortisolemia causes a wide array of organ and immune changes (Tafet and Bernardini 2003, Duman 2004, Gubba et al. 2004).

One of the most affected structures is the hippocampus which expresses high numbers of steroid receptors (Brown et al. 1999, Sheline et al. 2002). Hippocampus has a key role in declarative memory tasks and many other cognitive functions. It is also interconnected to the limbic system, participating in the recognition and regulation of emotional states as well as in the vegetative and autonomic function control, including HPA and sympathoadrenal system regulation (Sheline et al. 2002, Tafet and Bernardini 2003). Adrenal steroids modulate excitability of hippocampal neurons and interfere with the process of dendritic remodeling in CA3 hippocampal region, causing hippocampal dendritic atrophy (Brown et al. 1999, McEwen et al. 2002, Sheline et al. 2002, Hayley et al. 2005). Stress also impairs the process of adult neurogenesis, causing robust reduction in 
the number of newly generated cells in the hippocampal dentatus gyrus within various stress paradigms (Czech et al. 2002, Duman 2004). Newly generated cells are functionally connected in the neuronal circuitry. Reduced adult neurogenesis is hypothesized to cause reduced ability of the hippocampus to cope with novelty and complex tasks leading to inadequate information processing at the interface systems involved in learning and affect regulation (Jakobs et al. 2000, Nestler et al. 2002, Kempermann et al. 2004, Doetsch and Hen 2005).

Today, mainstream therapy of depression via G-protein receptors and modulation of intracellular signalization cascade results in the activation of transcription factors, with subsequent increase of growth factor production; most notable are the studies of brainderived growth factor (Duman and Monteggia 2006). This "neurotrophin hypothesis of depression" assumes that deficiency in the neurotrophin signalization systems with effects on cellular plasticity, viability and neurogenesis together with an enhancement of apoptotic processes caused by increased cortisol and proinflammatory cytokines levels play an important role in the depression etiopathogenesis (Aberg et al. 2000, Jacobs et al. 2000, Gould and Manji 2002, Nestler et al. 2002, Kempermann and Kronenberg 2003, Duman 2004, Duman and Monteggia 2006, Leonard 2006).

This is supported by the study of Alfonso et al. (2004) relating psychosocial stress and hippocampus response using model tree shrews. These authors screened two subtractive hippocampal cDNA libraries generated from RNA of cortisol-treated animals. Comparing transcript levels of stressed and control groups, four differences were demonstrated: nerve growth factor (NGF), membrane glycoprotein protein 6a (M6a), CDC-like kinase 1 (CLK-1), and $\alpha$ subunit of Gq protein (GNAQ) transcript levels were reduced by chronic psychosocial stress. All genes are related to neuronal differentiation, in agreement with previous findings of dendrite retraction and impairment of neurogenesis. Treatment by antidepressant clomipramine prevents these processes (with the exception of unchanged NGF). This study also supports the concept that stress and/or depressive disorders are accompanied by the neuronal dedifferentiation at least in the hippocampal area and antidepressants can prevent these processes (Alfonso et al. 2004).

Brain imaging studies show reductions of a hippocampal volume correlated with lifetime duration of depression (Steffens et al. 2000, Sheline et al. 2002).
Reduction of the hippocampal volume is more prominent in depressive subjects exposed to trauma during childhood (Vithingham et al. 2002). Cell-counting studies have established that the major depressive disorder and bipolar illness are characterized by alterations in the density and size of neuronal and glial cells in frontolimbic brain regions (Rajkowska 2003). There is a decrease in the neuronal and glial cell sizes and densities in the orbito-frontal regions and dorsolateral prefrontal cortexes of subjects with mood disorders and alcohol dependence, with more marked pathology of glial population (Miguel-Hidalgo and Rajkowska 2003). Reduced subgenual glial numbers are more prominent in subjects with the family history of depression (Öngür et al. 1998). There are also reduced numbers of glial cells and glial/neuronal ratio in the amygdala (Bowley et al. 2002) and reduced astrocytic marker GFAP in the cerebellum of subjects with mood disorders (Fatemi et al. 2004). Apoptosis is considered as a mechanism responsible for cell loss of both neurons and glia in the hippocampal region, requiring prolonged and severe stress exposure to occur (Tacuma et al. 2004, Lucassen et al. 2006)

These findings from histopathological and cell counting studies suggest that depression, as a complex disorder affecting many cell populations, also involves glial cells. In this review we will focus mainly on astrocytes and model C6 glioma (astrocytoma) cells, keeping in mind that contribution of other glial elements, e.g. oligodendrocytes or microglia, is also very important.

\section{Astrocytes and etiopathogenesis of depression}

Astrocytes are the prevailing glial cell population in the CNS, outnumbering neurons by a factor of 2-10, depending on the brain area (O'Kusky and Collonier 1982). They form a plexiform net of cells connected by gap junctions, providing thus a way for buffering extracellular ion dysbalances caused by neuronal activity (Syková 2005). Astroglial cells are an essential component of blood brain barrier, and provide nutrient supply to neurons (Laming et al. 2000). Astrocytes express virtually all neuronal neurotransmitter receptors, ion channels and neurotransmitter uptake sites (Table 1) (Hösli and Hösli 1993, Porter and McCarthy 1997, Deschepper 1998, Verkhratsky and Steinhäuser 2000, Nakagawa and Schwartz 2004). There is an intensive bidirectional communication between neurons 
and glial cells at the synapses, a concept of "gliotransmission" and "tripartite synapse" was postulated where astrocytes are seen as active partners of neurons (Araque et al. 1999). Astrocytes participate in the neurotransmitter uptake from synaptic cleft, their synthesis from precursors, supply of neurotransmitter precursors to neuron and disposal of neurotransmitter excess (Danbolt 2001, Hertz and Zielke 2004). Released neurotransmitter can evoke $\mathrm{Ca}^{2+}$ concentration increases in astrocytes ensheathing the synaptic cleft which can signal back to the neuronal presynaptic terminal, and further increase or suppress the release of neurotransmitter (Cotrina et al. 2000, Parpura and Haydon 2000).

Astrocytes express both mineralocorticoid and glucocorticoid receptors, glucocorticoid levels regulate astrocytic reactivity and apoptosis, so that the downregulation of astrocytic growth factor production by glucocorticoids is demonstrated (Gubba et al. 2004). Glucocorticoids also inhibit glucose uptake by both astrocytes and neurons impairing thus complex brain energy metabolism (Horner et al. 1990).

Hippocampal atrophy observed in depression illness might be related to the altered excitatory amino acid system function. Excessive excitatory amino acid levels can be neurotoxic for neuronal terminals, neurons are in this respect greatly dependent on astrocyte clearance of elevated glutamate, because removal of glutamate is largely mediated by astrocytic transporters (Brown 1999, Danbolt 2001, Hertz and Zielke 2004). Elevated cAMP levels are demonstrated to enhance the expression of glutamate transporters (GLAST and GLT1) in rat astrocytes and regulate active calcium entry (Hughes et al. 2004, Pawlak et al. 2005). Growth factors, e.g. TGF- $\beta$ and EGF, increase expression of glutamate transporters on astrocytes (Zelenaia et al. 2000). This can exert a protective effect in the endangered hippocampal structures, e.g. apical dendrites of pyramidal neurons in C3 area, enhance glutamate uptake and prevent excitatory amino acid-induced impairments of long-term potentiation and dendritic remodeling.

Astrocytes are important regulators of synapse numbers during development and in adulthood and are necessary for synapse maturation, proper receptor density and receptor subunit composition (Wilson et al. 1998, Donato 2001, Slezak and Pfrieger 2003). There is also evidence for astrocyte influence in the process of adult neurogenesis taking place in the subventricular and subgranular hippocampal zones (Seri et al. 2001,
Table 1. Astrocyte receptors and membrane transporters.

\begin{tabular}{|c|c|}
\hline $\begin{array}{l}\text { Adrenergic } \beta_{2,} \beta_{1,} \alpha_{1}, \alpha_{2 A / D} \\
\text { receptors }\end{array}$ & $\begin{array}{l}\text { Junker et al. 2002, } \\
\text { Hösli and Hösli 1993, } \\
\text { Porter et al. } 1997\end{array}$ \\
\hline $\begin{array}{l}\text { Serotonergic } 5 H T_{1 A}, 5-H T_{2 A} \text {, } \\
5 H T_{7} \text { receptors }\end{array}$ & $\begin{array}{l}\text { Wilson et al. } 1998 \text {, } \\
\text { Barnes and Sharp } \\
\text { 1999, Manev et al. } \\
\text { 2001, Hannson et al. } \\
1990\end{array}$ \\
\hline $\begin{array}{l}G A B A_{A}, G A B A_{B 1 a}, G A B A_{B 1 b}, \\
G A B A_{B 2} \text { receptors }\end{array}$ & $\begin{array}{l}\text { Charles 2003, Porter et } \\
\text { al. } 1997\end{array}$ \\
\hline $\begin{array}{l}\text { Glutamate AMPA/kainate, } \\
\text { NMDA, } m G L U R s 1, \\
m G L U R s 5 \text { receptors }\end{array}$ & $\begin{array}{l}\text { Porter et al. 1997, } \\
\text { Hertz and Zielke } 2004\end{array}$ \\
\hline
\end{tabular}

Purinergic $P 1, P 2 X_{1}, P 2 X_{1}$, Müller et al. 1995, $P 2 Y_{2}, \quad P 2 X_{3}, \quad P 2 X_{4}, \quad P 2 X_{6}$, Washburn and Neary $P 2 X_{7}, P_{2} Y_{2}, P_{2} Y_{4}$ receptors 2006

\begin{tabular}{ll}
\hline $\begin{array}{l}\text { Acetylcholine nicotinic } \\
\text { receptors }\end{array}$ & $\begin{array}{l}\text { Sharma and } \\
\text { Vijayaraghavan 2001 }\end{array}$ \\
\hline $\begin{array}{l}\text { Dopamine } D_{1}, D_{3}, D_{4}, D_{5} \\
\text { receptors }\end{array}$ & $\begin{array}{l}\text { Ohta et al. 2003, } \\
\text { Myiazaki et al. 2004 }\end{array}$ \\
\hline
\end{tabular}

Serotonin transporter SERT Fuller and Wong 1990, Bal et al. 1997, Inazu et al. 2001

\begin{tabular}{ll}
\hline Norepinephrine transporter & Inazu et al. 2003, \\
NET, uptake 2 transporter & Schildkraut and Money \\
& 2004 \\
\hline
\end{tabular}

Glutamate transporters Danbolt 2001, Pawlak GLAST and GLT1 et al. 2005

Receptors for ńeurotrophic Müller et al. 1995, factors (NGF, BDNF, IGF, Hughes et al. 2004, $F G F, V E G R, E G F R, N T-3) \quad$ Pawlak et al. 2005

Receptors for cytokines Haddad et al. 2002, (CNTF, IL 1 $\beta$, IL1ra, INF- $\gamma$, Nakagawa and IL4, IL 6, IL10, TGF $\beta, T N F \alpha$ ) Schwartz 2004

Peptide receptors for Deschepper 1998,

VIP, somatostatin, oxytocin, Porter et al. 1997 vasopressin, ANP, bradykin, thrombin

Nakayama et al. 2003, Hagg 2005). Interesting novel findings indicate glial gene $\mathrm{Ndrg} 2$, with putative roles in neuronal differentiation, synapse formation and axonglial interactions regulated by glucocorticoids and 
antidepressants as a candidate for vulnerability gene to depression development (Nichols et al. 2005).

Following noxious insults associated with neuronal damage, astrocytes proliferate and change cell morphology, accumulation of cytoplasmic fibrillary material and profile of expressed receptors and adhesion molecules (Ridet et al. 1997, Sofroniew 2005). These reactive astrocytes produce neurotrophins, cytokines and chemokines which serve as mediators of the host defense system, inflammatory response and signals among astrocytes, neurons and microglia (Müller et al. 1995, Nakagawa and Schwartz 2004, Hauwel et al. 2005). Astrocytes are the main cell population, responsible for limiting inflammatory reactions within CNS, proinflammatory cytokines, prostaglandins and nitric oxide released during inflammatory response can attenuate the negative feedback and rise to the levels which can be deleterious for the neurons and other cells. For example, astrocytes lacking $\beta_{2}$-adrenoreceptors play a role in multiple sclerosis pathogenesis (De Keyser et al. 2004). There is a negative interference of inflammation with induction of long-term potentiation, neurite sprouting and neurogenesis in hippocampus (Vereker et al. 2001, Hayley et al. 2005). There is also an increase of apoptosis rate (Shiepers et al. 2005, Lucassen et al. 2006).

There is also an important involvement of astrocytes in serotonin metabolism. Depletion of serotonin precursor tryptophane in the diet is causing serotonin level reductions in the brain which is correlating with depressive symptomatology (Neumeister 2003, Leonard 2006). Tryptophane is metabolized by tryptophane hydroxylases to serotonin or alternatively by dioxygenases to kynurenine. Kynurenine is further metabolized to neurotoxic metabolites or neuroprotective kynurenic acid. Activity of dioxygenases is increased by cortisol and pro-inflammatory cytokines, e.g. IL-6 or INF- $\gamma$. Activated microglia is producing mostly neurotoxic metabolites 3-hydroxyanthranil acid and quinolinic acid, the main astrocyte metabolite is neuroprotective kynurenine (Guillemin et al. 2005). Astrocytes are also metabolizing quinolinic acid produced by the microglia, reducing thus neurotoxicity associated with microglial activation (Guillemin et al. 2001).

Reductions in neuronal size and density in certain areas observed in depression can be indicative of diminished glial ability to support full cell size and proper dendrite arborization. Given indispensable function of astrocytes in neuronal energy metabolism, reductions in the number of glial cells in the frontal lobes can participate in the lowered metabolism observed in these regions during a depressive episode. Astrocytes contain high levels of antioxidants and antioxidant enzymes. Reduced neuron supportive functions due to compromised astrocyte numbers or function can thus cause neurons to become more vulnerable to excessive corticosteroid mediated, excitotoxic glutamate, quinolinic acid or reactive oxygen species mediated damage (Drukarch et al. 1998, Brown et al. 1999, Brown 1999, Tacuma et al. 2004). Astrocyte-derived growth factors provide neuroprotection in various damage models (Junker et al. 2002, Nakagawa and Schwartz 2004, Tacuma et al. 2004). Astrocytes can further support neuronal viability by secretion of other neuroprotective factors and by restricting the inflammatory response and microglial activation (Müller et al. 1995, Villoslada and Genain 2004, Hauwel et al. 2005).

\section{Effect of antidepressants on astrocytes}

Several different classes of pharmacological agents are currently used for treatment of depression. These include monoamine oxidase inhibitors (MAO), nonselective inhibitors of monoamine uptake, tricyclic drugs e.g. imipramine, amitriptyline or desipramine, selective inhibitors of serotonin reuptake (SSRIs) like fluoxetine, sertraline or citalopram, inhibitors of noradrenaline reuptake and drugs inhibiting uptake of both monoamines, e.g. venlafaxine or milnacipran. Antidepressive effect proves also tianeptine which enhances uptake of monoamines on the synapses and is supposed to reverse stress-induced changes in the hippocampal formation and modulate glutamate receptors function (McEven et al. 2002). The main mechanism to terminate the action of synaptically released transmitters is the uptake by transporters which are present both on neurons and astrocytes (Fuller and Wong 1990, Bal et al. 1997, Inazu et al. 2001, 2003).

Norepinephrine transporter (NET) is sensitive to tricyclic drugs like desipramine and imipramine as well as to the mixed serotonin/noradrenaline uptake inhibitor milnacipram (Inazu et al. 2003). Elevation of norepinephrine levels by a blockade of uptake has a profound effect on astrocytic neurotransmitter receptor expression and cellular signalization cascade modulation. Astrocytes as a major cell population expressing $\beta_{1}$ - and $\beta_{2}$-adrenoreceptors in the brain (Hösli and Hösli 1993) 
are responding to antidepressant desipramine by decreasing the density of receptors (Sapena et al. 1996). Norepinephrine present in the synapse or other extraneuronal spaces can also be taken up into adjacent glia by a mechanism known as uptake 2, the extraneuronal monoamine transporter. This uptake 2 transporter is inhibited by formation of normetanephrine in glia by catechol O-methyltransferase from epinephrine. Thus astrocytes actively participate in an increase of synaptic norepinephrine and potentiate action of norepinephrine reuptake inhibitor antidepressants (Schildkraut and Mooney 2004).

Astrocytic serotonin sodium-dependent transporter SERT is sensitive to tricyclic drugs as well as to SSRIs and its expression is downregulated by SSRIs (Bal et al. 1997, Inazu et al. 2001, Benmansour et al. 2002). Its expression and serotonin uptake are positively regulated by fibroblast growth factor (Kubota et al. 2001). By binding to astrocytic $5 \mathrm{HT}_{1}$ receptors, serotonin stimulates production of neurotrophic $\mathrm{S} 100 \beta$ which is also produced after exposure to SSRI fluoxetine (Wilson et al. 1998, Donato 2001, Manev et al. 2001). The plasma level of $\mathrm{S} 100 \beta$ was significantly higher in patients with major depression and positively correlated with a response after 4 weeks of treatment (Arolt et al. 2003). Stimulation of 5$\mathrm{HT}_{2 \mathrm{~A}}$ receptors enhances the turnover of phosphoinositide and cAMP accumulation, there is a potentiation of $\beta$ adrenoreceptor stimulated accumulation of cAMP. Furthermore, in the presence of both noradrenaline and serotonin receptor agonists, the accumulation of cAMP is increased, and each of them alone can also cause cAMP accumulation (Hansson et al. 1990).

Influence of antidepressant treatment on glutamate system function is also studied. Tricyclic antidepressants when administered chronically have a modulatory effect on NMDA receptors; NMDA antagonist MK-801 produces a similar effect (Nowak et al. 1993). A stress-induced increase of glial glutamate transporter GLT1a has also been demonstrated, while the administration of antidepressant tianeptine eliminates this effect, being concurrent with downregulation of NMDA-receptor subunits (McEwen et al. 2002).

With respect to the suspected neurotrophin shortage in depression, production of growth factors by astrocytes following antidepressant treatment was investigated. Chronic administration of antidepressants amitriptyline, clomipramine, mianserine, fluoxetine and paroxetine significantly increases glia-derived neurotrophic factor (GDNF) release from C6 glioma cells
(Hisaoka et al. 2001). This GDNF release is further potentiated by serotonin (Hisaoka et al. 2004). Activation of $\beta_{2}$-adrenoreceptors by clenbuterol induced the synthesis of nerve growth factor (NGF), fibroblast growth factor (FGF) and transforming growth factor $\beta 1$ (TGF $\beta 1)$ and provided neuroprotection against glutamateinduced and ischemic neuronal damage (Junker et al. 2002). Noradrenaline stimulates C6 glioma and cortical astrocytic cells to produce NGF via $\beta$-adrenergic receptor stimulation and adenylylcyclase activation (Stone and Ariano 1989).

Production of growth factors also seems to be regulated by dopamine $D_{1}$ and $D_{2}$ receptor agonists which may be required for NGF and glia-derived growth factor (GDGF) production by astrocytes (Ohta et al. 2003). Production of brain-derived neurotrophic factor by mouse astrocytes is also potentiated by dopaminergic stimulation (Inoue et al. 1997). MAO B inhibitor selegiline also stimulates growth factor (NGF, BDNF, and GDNF) production by mouse astrocytes (Mizuta et al. 2000).

All monoamines (noradrenaline, serotonin or dopamine) are able to significantly increase BDNF astrocyte synthesis and secretion suggesting the existence of a positive reciprocal interaction between monoaminergic neuronal activity and astrocyte neurotrophic support in neuron-astrocyte crosstalk which has a dynamic role in mediating neuronal plasticity and trophic functions in the brain (Mojca-Juric et al. 2006).

\section{Major depression and cell signaling}

Biochemical approach to mood disorders and antidepressant action is based on monoamine theories describing lowered amounts of serotonin and norepinephrine in the synaptic cleft, and antidepressant influenced inhibition of the neurotransmitter reuptake into nerve terminals (Gould and Manji 2002, Avissar and Schreiber 2006). Attention is also focused on transmembrane signal transduction from neurotransmitter receptor coupled to heterotrimeric guanine-nucleotide binding proteins ( $\mathrm{G}$ proteins), effector systems (enzymes, ion channels) and subsequent intracellular response.

Trimeric $G$ proteins are composed of $\alpha, \beta$ and $\gamma$ subunits. In the activated state especially $\mathrm{G} \alpha$ subunits play a key role in transmembrane signaling from receptor-ligand complet (neurotransmitter, hormone, chemokine, etc.) to effector enzymes - adenylylcyclase ( $\left.\mathrm{G} \alpha_{\mathrm{s}}, \mathrm{G} \alpha_{\mathrm{i}_{1,2}}\right)$ and phospholipase $\mathrm{C}\left(\mathrm{G} \alpha_{\mathrm{q} / 11}\right)$, producing second messengers cAMP and 1,4,5 inositoltriphosphate 
(Spiegel 1996), respectively. Subsequent intracellular events predominantly regulate cascade of protein phosphorylation reactions by kinases. $G$ proteins play a role in molecular switches in complex biological processes, such as synaptic plasticity, neuronal sprouting and cellular differentiation including early stages of neurogenesis, providing thus a mechanism for the epigenetic control of neuronal differentiation (Strubing et al. 1997, Avissar and Schreiber 2006).

Various studies are concerned with the involvement of $\mathrm{G}$ proteins in pathophysiology, diagnosis and treatment of mood disorders, modulation of $\mathrm{G}$ protein coupled neurotransmitter receptors and regulation of $G$ protein function by arrestins, etc. (Gould and Manji, 2002, Avissar and Schreiber 2002, 2006). Furthermore, there was found an association between $G \beta$ subunit expression or $G$ protein $\beta 3$ subunit gene polymorphism and antidepressant effect in major depression (Kovářru et al. 2001, Lee et al. 2004). Altered signal transduction components, especially $\alpha$ subunit of G protein expression and/or function, as well as changed mRNA levels were found in the postmortem brain tissue of patients with major depression and bipolar disorder (Young et al. 1993). Other studies revealed both $G$ protein-influenced cAMP synthesis and G protein- induced activation of phosphoinositide signal transduction in postmortem brain cortex regions of suicide victims with major depression (Pacheco et al. 1996). In contrast, there is decreased phosphoinositide metabolism in postmortem brain samples of bipolar affective disorder subjects (GonzalesMaeso et al. 2002).

In addition, the analyses of peripheral blood granulocytes or thrombocytes from depressive patients confirmed the relationship between alteration in $G$ proteins and decreased $\mathrm{G}$ protein function in depression, and increased levels and the function of $G$ proteins in bipolar disorder (Gould and Manji 2002, Avissar and Schreiber 2006). We demonstrated dynamic changes in levels of both $G \alpha_{q / 11}$ and $G \alpha_{s}$ subunits of peripheral blood granulocytes of patients with unipolar depression during fluoxetine administration on days 3-28 (Kovářů et al. 2000, Kovářů and Kovářů 2005). Granulocytes are effectors of natural immunity likewise natural killer (NK) cells. Blunted peripheral blood NK cytotoxicity was demonstrated in major depression (Reynaert et al. 1995).

\section{Antidepressants and cell signaling}

Antidepressant effects during depressive disorders is based mainly on the inhibition of reuptake of biogenic amines - serotonin (5-HT), norepinephrine and/or dopamine into presynaptic nerve terminals (Gould and Manji 2002, Avissar and Schreiber 2006). Furthermore, antidepressants cause downregulation of $\beta$-adrenergic, $5-\mathrm{HT}_{1}$ and $5-\mathrm{HT}_{2}$ receptors at the postsynaptic level, when administered chronically. Decreased monoamine receptor densities following antidepressant treatment can also be seen in cell culture systems, such as C6 glioma cells lacking presynaptic input. Thus, monoamine receptor downregulation is directly resulting from postsynaptic action of the antidepressants. Reports concerning antidepressant postreceptor effects on $\mathrm{G}$ proteins involve both proximal effects on receptor coupled to $G$ protein and distal effects on $G$ protein-effector enzymes, adenylylcyclase and phospholipase $\mathrm{C}$ which are producing second messengers cAMP and 1,4,5-inositoltriphosphate.

Receptor-G protein coupled interactions are tightly regulated by mechanisms of desensitization, internalization, downregulation, and resensitization which are protecting cells from overstimulation. These mechanisms involve activities of two families of proteins: i) $G$ protein-coupled receptor kinases, serine-threonine kinases, capable of phosphorylation of receptor and thus uncoupling receptor-G protein, and ii) beta-arrestins with "scaffold" function of the G protein, transducing signal leading to activation of mitogen-associated protein (MAP) kinase cascade. MAP kinase via specific kinases regulates a number of intracellular events, including apoptotic signals (Avissar and Schreiber 2006).

In vitro studies contribute to the clarification of the molecular basis of antidepressant action involving G proteins as postreceptor components (Alt et al. 2001, Donati and Rasenick 2005). Cell cultures represent alternative bioassay models to animal experiments. C6 glioma established cell line of astrocyte origin is used in the studies exploring antidepressant effects (Mareš et al. 1991, Kovářů et al. 2001, Donati and Rasenick 2005). Acute antidepressant administration lasts $24 \mathrm{~h}$, chronic 5-day administration to C6 glioma cell cultures is comparable with 3-week antidepressant treatment of rats (Chen and Rasenick 1995).

According to our results, acute fluoxetine effect evoked a decreased level of $\mathrm{G} \alpha_{\mathrm{q} / 11}$ subunit in C6 glioma cells, whereas an increased $\mathrm{G} \alpha_{\mathrm{q} / 11}$ level was observed after chronic exposure. Acute fluoxetine administration causing a reduced membrane $G \alpha_{q / 11}$ amount was linked to subunit translocation into cytoplasm where it was determined 
(Kovářů et al. 1997, 1998). Reduced membrane G $\alpha_{\mathrm{q} / 11}$ subunit levels caused a lower degree of phospholipase $\mathrm{C}$ signaling with a subsequent decreased substrate 1,4,5inositoltriphosphate formation. Anti-depressants from different classes are able to induce $G \quad \alpha$ subunit translocation into the cytoplasm (Donati and Rasenick 2005). Intracellular consequences of fluoxetine administration on C6 glioma cells were demonstrated by apoptotic events in contrast to ineffective imipramine or amitriptyline (Š́panová et al. 1997). MAP kinase activation participating in apoptotic signals was detected in fluoxetintreated cultures of rat astrocytes (Mercier et al. 2004).

We also studied in vitro chronic effects of sertraline, citalopram (SSRIs) and mirtazapine (noradrenergic and serotonergic antidepressant) in comparison with tricyclic imipramine, amitriptyline or desipramine. Results show that $\mathrm{G} \alpha$ subunit profiles are antidepressant-dependent and are not affected by TCA administration. The data available demonstrate antidepressant-induced cell signal transduction pathway modulation via both effector enzymes, adenylylcyclase $(\mathrm{G} \alpha \mathrm{s})$ and phospholipase $\mathrm{C}(\mathrm{G} \alpha \mathrm{q} / 11)$ (Kovářů et al. 1998, 1999, 2001).

When citalopram effects on both rat C6 glioma cells after in vitro chronic treatment and rat brain in vivo were compared, similarities in G $\alpha$ profiles were observed (Fig. 1). In vivo citalopram effects were comparable in the brain and the spleen, indicating a similar cell signaling response in functionally different systems (Fišerová et al. 1997, Kovářů et al. 2000, 2001, Fišerová et al. 2002).

\section{Conclusions}

Despite several decades of research, the exact neurobiological substrate of depression and mechanisms of antidepressant drug action are still unknown. There is a complex disturbance of homeostatic functions in depression, comprising immune, endocrine and central nervous systems, which are regulated and/or corrected by antidepressant treatment. As suggested by many authors, disturbances in cellular plasticity processes, neurogenesis and suppression of reparation processes are the crucial changes at the cellular level in depression (Jacobs et al. 2000, Nestler et al. 2002, Kempermann and Kronenberg 2003, Duman 2004, Leonard 2006). Impairment of neural connectivity results in the aberrant information processing in neural circuits critical for mood regulation.

Depression is often accompanied by inflammatory changes and hypercortisolemia which are

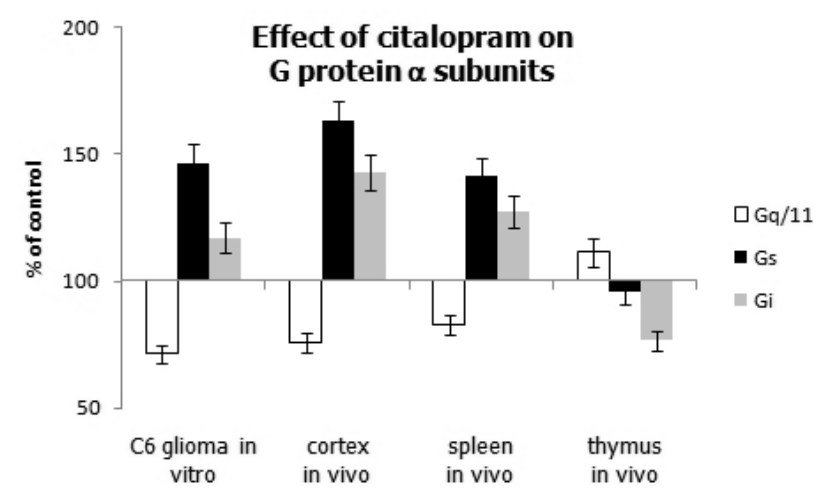

Fig. 1. Effect of citalopram in vitro and in vivo in the rat. Each result is the mean \pm S.E.M. of 7-9 measurements. For details see Kovářů et al. (2001).

both pro-apoptotic. Many findings demonstrate an increase of apoptotic processes and atrophic changes in the hippocampus and frontal lobes as well as other structural neuronal alterations (Hayley et al. 2005, Shiepers et al. 2005, Lucassen et al. 2006).

Nevertheless, the present prevailing opinion considering only neuronal population as a substrate of a disorder and the only target of antidepressant medication is not further sustainable with a expanding knowledge demonstrating close functional cooperation between neurons and supportive glia in health and disease. This close cooperation is also reflected in the depression pathogenesis where degeneration of neuronal populations in certain regions is also accompanied by glial astheny and impairment of neuronal metabolism which is largely glia-dependent.

As we try to demonstrate, antidepressants affect glial cell signal transduction, as evidenced by changed G protein levels and second messenger changes. Treatment also modulates complex cell responses and production of many substances, necessary for neuronal health and survival, including a wide array of growth factors. The antidepressant treatment effect, which in some aspects opposes the effect of stress on neurons, is therefore not limited to neuronal population. Antidepressants also affect astrocytes, which are the major source of the neurotrophic and neuroprotective substances, thus supporting neuroplasticity events. Therefore, modulation of astrocyte activity seems to be a logical step in complex pharmacological treatment of depression as well as of other neuropsychiatric disorders with a neurodegenerative component. Considering significant differences in the antidepressant effects on astrocyte cell signal transduction, it remains a matter of further research to identify drugs with specific 
modulatory effects on astrocytic function or production of neurotrophic molecules.

\section{Conflict of Interest}

There is no conflict of interest.

\section{Acknowledgements}

Supported by grants: GA ČR 524/05/0267, MSM 0021620849 and IAA 500200620.

\section{Abbreviations}

cAMP - cyclic adenosine monophosphate, CNS - central nerve system, EAA - excitatory amino acid, EGF epidermal growth factor, GFAP - glial fibrillar acidic protein, IL - interleukin, NMDA - N-methyl D-aspartate, SSRI - selective serotonin reuptake inhibitor, TCA tricyclic antidepressant, TNF - tumor necrosis factor.

\section{References}

ABERG MA, ABERG ND, HEDBACKER H, OSCARSSON J, ERIKSSON PS: Peripheral infusion of IGF-I selectively induces neurogenesis in the adult rat hippocampus. $J$ Neurosci 20: 2896-2903, 2000.

ALFONSO J, POLLEVICK GD, VAN DER HART MG, FLUEGGE G, FUCHS E, FRASCH AC: Identification of genes regulated by chronic psychosocial stress and antidepressant treatment in the hippocampus. Eur J Neurosci 19: 659-666, 2004.

ALT A, MCFADYEN IJ, FAN CD, WOODS JH, TRAYNOR JR: Stimulation of guanosine-5'-o-(3$\left[{ }^{35} \mathrm{~S}\right]$ thio)triphosphate binding in digitonin-permeabilized C6 rat glioma cells: evidence for an organized association of mu-opioid receptors and G protein. J Pharmacol Exp Ther 298: 116-121, 2001.

ARAQUE A, PARPURA V, SANZGIRI RP, HAYDON PG: Tripartite synapses: glia, the unacknowledged partner. Trends Neurosci 22: 208-215, 1999.

AROLT V, PETERS M, ERFURTH A, WIESMANN M, MISSER U, RUDOLF S, KIRCHNER H, ROTHERMUNDT M: S100B and response to treatment in major depression: a pilot study. Eur Neuropsychopharmacol 13: 235239, 2003.

AVISSAR S, SCHREIBER G: Toward molecular diagnostics of mood disorders in psychiatry. Trends Mol Med 8: 294$300,2002$.

AVISSAR S, SCHREIBER G: The involvement of G proteins and regulators of receptor-G protein coupling in pathophysiology, diagnosis and treatment of mood disorders. Clin Chim Acta 336: 37-47, 2006.

BAL N, FIGUERAS G, VILARO MT, SUNOL C, ARTIGAS F: Antidepressant drugs inhibit a glial 5-hydroxytryptamine transporter in rat brain. Eur J Neurosci. 9: 1728-1738, 1997.

BARNES NM, SHARP T: A rewiew of central 5-HT receptors and their function. Neuropharmacology 38: 1083-1152, 1999.

BENMANSOUR S, OWENS WA, CECCHI M, MORILAK DA, FRAZER A: Serotonin clearance in vivo is altered to a greater extent by antidepressant-induced downregulation of the serotonin transporter than by acute blockade of this transporter. J Neurosci 22: 6766-6772, 2002.

BOWLEY MP, DREVETS WC, ÖNGÜR D, PRICE JL: Low glial numbers in the amygdala in major depressive disorder. Biol Psych 52: 404-412, 2002.

BROWN DR: Neurons depend on astrocytes in a coculture system for protection from glutamate toxicity. Mol Cell Neurosci. 13: 379-389, 1999.

BROWN ES, RUSH AJ, MCEWEN BS: Hippocampal remodeling and damage by corticosteroids: implications for mood disorders. Neuropsychopharmacology 21: 474-484, 1999.

COTRINA ML, LIN JH, LOPEZ-GARCIA JC, NAUS M, NEDERGAARD M: ATP-mediated glia signaling. J Neurosci 20: 2835-2844, 2000.

COVIC T, TYSON G, SPENCER D, HOWE G: Depression in rheumatoid arthritis patients: demographic, clinical and psychological predictors. J Psychosom Res 60: 469-476, 2006.

CHEN J, RASENICK M: Chronic treatment of C6 glioma cells with antidepressant drugs increases functional coupling between a G protein (Gs) and adenylyl cyclase.J Neurochem 64, 724-732, 1995. 
CZECH B, WELT T, FISCHER AK, ERHARDT A, SCHMITT W, MULLER MB, TOSCHI N, FUCHS E, KECK ME: Chronic psychosocial stress and concomitant repetitive transcranial magnetic stimulation: effects on stress hormone levels and adult hippocampal neurogenesis. Biol Psychiatry 52: 1047-1056, 2002.

DANBOLT NC: Glutamate uptake. Prog Neurobiol 65: 1-105, 2001.

DE KEYSER J, ZEINSTRA E, WILCZAK N: Astrocytic $\beta_{2}$ adrenoreceptors receptors and multiple sclerosis. Neurobiol. Dis 15: 331-339, 2004.

DESCHEPPER CF: Peptide receptors on astrocytes. Front Neuroendocrinol 19: 20-46, 1998.

DIAMOND M, KELLY JP, CONNOR TJ: Antidepressants suppress production of the $\mathrm{Th}_{1}$ cytokine interferon- $\gamma$, independent of monoamine transporter blockade. Eur Neuropsychopharmacol 16: 481-490, 2006.

DOETSCH F, HEN R: Young and excitable: the function of new neurons in the adult mammalian brain. Curr Opin Neurobiol 15: 121-128, 2005.

DONATI RJ, RASENICK MM: Chronic antidepressant treatment prevents accumulation of gsalpha in cholesterol-rich, cytoskeletal-associated, plasma membrane domains (lipid rafts). Neuropsychopharmacology 30: 1238-1245, 2005.

DONATO R: S100: a multigenic family of calcium-modulated proteins of the EF-hand type with intracellular and extracellular functional roles. Int J Biochem Cell Biol 33: 637-668, 2001.

DUMAN RS: Depression: a case of neuronal life and death? Biol Psychiatry 56: 140-145, 2004.

DUMAN RS, MONTEGGIA LM: A neurotrophic model for the stress-related mood disorders. Biol Psychiatry 59: 1116-1127, 2006.

DRUKARCH B, SCHEPENS E, STOOF JC, LANGEVELD CH, VAN MUISWINKEL FL: Astrocyte-enhanced neuronal survival is mediated by scavenging of extracellular reactive oxygen species. Free Radic Biol Med 25: 217-220, 1998.

FATEMI SH, LAURENCE JA, ARAGHI-NIKNAM M, STARY JM, SCHULZ SC, LEE S, GOTTESMAN II: Glial fibrillary acidic protein is reduced in cerebellum of subjects with major depression, but not schizophrenia. Schizophr Res 69: 317-323, 2004.

FIŠEROVÁ A, KOVÁŘŮ H, HAJDUOVA Z, MAREŠ V, STAREC M, KŘEN V, FLIEGER M, POSPÍŠIL M: Neuroimmunomodulation of natural killer (NK) cells by alkaloid derivates. Physiol Res 46: 119-125, 1997.

FIŠEROVÁ A, STAREC M, KULDOVÁ M, KOVÁŘŮ H, PÁV M, VANUCCI L, POSPÍŠIL M: Effects of $D_{2}$ dopamine and alpha-adrenoceptor antagonists in stress induced changes on immune responsiveness of mice. J Neuroimmunol 130: 55-65, 2002.

FULLER RW, WONG DT: Serotonin uptake and serotonin uptake inhibition. Ann N Y Acad Sci 600: 68-78, 1990.

GONZALES-MAESO J, RODRIGUES-PUERTAS R, MEANA JJ, GARCIA-SEVILLA JA, GUIMON J: Neurotransmitter receptor-mediated activation of G-proteins in brains of suicide victims with mood disorders. Mol Psychiatry 7: 755-767, 2002.

GOULD TD, MANJI HK: Signaling networks in the pathophysiology and treatment of mood disorders. $J$ Psychosom Res 53: 687-697, 2002.

GUBBA EM, FAWCETT JW, HERBERT J: The effects of corticosterone and dehydroepiandrosterone on neurotrophic factor mRNA expression in primary hippocampal and astrocyte cultures. Brain Res Mol Brain Res 127: 48-59, 2004.

GUILLEMIN GJ, KERR SJ, SMYTHE GA, SMITH DG, KAPOOR V, ARMATI PJ, CROITORU J, BREW BJ: The kynurenine pathway metabolism in human astrocytes: paradox for neuroprotection. $J$ Neurochem 78: 842-853, 2001.

GUILLEMIN GJ, SMYTHE G, TAKIKAWA O, BREW BJ: Expression of indoleamine 2,3- dioxygenase and production of quinolinic acid by human microglia, astrocytes and neurons. Glia 49: 15-23, 2005.

HADDAD JJ, SAADE NE, SAFIEH-GARABEDIAN B: Cytokines and neuro-immune-endocrine interactions: a role for the hypothalamic-pituitary-adrenal revolving axis. J Neuroimmunol 133: 119, 2002.

HAGG T: Molecular regulation of adult CNS neurogenesis: an integrated review. Trends Neurosci 28: 589-595, 2005.

HANSSON E, SIMONSSON P, ALLING C: Interactions between cyclic AMP and inositol phosphate transduction systems in astrocytes in primary culture. Neuropharmacology 29: 591-598, 1990. 
HAUWEL M, FURON E, CANOVA C, GRIFFITHS M, NEAL J, GASQUE P: Innate (inherent) control of brain infection, brain inflammation and brain repair: the role of microglia, astrocytes, "protective" glial stem cells and stromal ependymal cells. Brain Res Brain Res Rev 48: 220-233, 2005.

HAVRDOVA E: Aggressive multiple sclerosis - is there a role for stem cell transplantation? J Neurol 252 (Suppl 3): iii34-iii37, 2005.

HAYLEY S, POULTER MO, MERALI Z, ANISMAN H: The pathogenesis of clinical depression: stressor and cytokine induced alterations of cytoplasticity. Neuroscience 135: 659-678, 2005.

HERTZ L, ZIELKE HR: Astrocytic control of glutamatergic activity: astrocytes as stars of the show. Trends Neurosci 27: 735-743, 2004.

HISAOKA K, NISHIDA A, KODA T, MIYATA M, ZENSHO H, MORINOBU S, OHTA M, YAMAWAKI S: Antidepressant drug treatments induce glial cell line-derived neurotrophic factor (GDNF) synthesis and release in rat C6 glioblastoma cells. $J$ Neurochem 79: 25-34, 2001.

HISAOKA K, NISHIDA A, TAKEBAYASHI M, KODA T, YAMAWAKI S, NAKATA Y.: Serotonin increases glial cell line-derived neurotrophic factor release in rat C6 glioblastoma cells. Brain Res 1002: 167-170, 2004.

HORNER HC, PACKAN DR, SAPOLSKY RM: Glucocorticoids inhibit glucose transport in cultured hippocampal neurons and glia. Neuroendocrinology 52: 57-64, 1990.

HÖSLI E, HÖSLI L: Receptors for neurotransmitters on astrocytes in the mammalian central nervous system. Prog Neurobiol 40: 477-506, 1993.

HUGHES EG, MAGUIRE JL, MCMINN MT, SCHOLZ RE, SUTHERLAND ML: Loss of glial fibrillary acidic protein results in decreased glutamate transport and inhibition of PKA-induced EAAT2 cell surface trafficking. Brain Res Mol Brain Res 124: 114-123, 2004.

INAZU M, TAKEDA H, IKOSHI H, SUGISAWA M, UCHIDA Y, MATSUMIYA T: Pharmacological characterization and visualization of the glial serotonin transporter. Neurochem Int 39: 39-49, 2001.

INAZU M, TAKEDA H, MATSUMIYA T: Functional expression of the norepinephrine transporter in cultured rat astrocytes. J Neurochem 84: 136-144, 2003.

INOUE S, SUSUKIDA M, IKEDA K, MURASE K, HAYASHI K: Dopaminergic transmitter up-regulation of brainderived neurotrophic factor (BDNF) and nerve growth factor (NGF) synthesis in mouse astrocytes in culture. Biochem Biophys Res Commun 238: 468-472, 1997.

JACOBS BL, PRAAG H, GAGE FH: Adult brain neurogenesis and psychiatry: a novel theory of depression. Mol Psychiatry 5: 262-269, 2000.

JUNKER V, BECKER A, HUHNE R, ZEMBATOV M, RAVATI A, CULMSEE C, KRIEGLSTEIN J: Stimulation of beta-adrenoceptors activates astrocytes and provides neuroprotection. Eur J Pharmacol 446: 25-36, 2002.

KELLEY KW, BLUTHE RM, DANTZER R, ZHOU JH, SHEN WH, JOHNSON RW, BROUSSARD SR: Cytokineinduced sickness behavior. Brain Behav Immun 17 (Suppl 1): S112-S118, 2003.

KEMPERMANN G, KRONENBERG G: Depressed new neurons- adult hippocampal neurogenesis and a cellular plasticity hypothesis of major depression. Biol Psychiatry 54: 499-503, 2003.

KEMPERMANN G, WISKOTT L, GAGE FH: Functional significance of adult neurogenesis. Curr Opin Neurobiol 14: 186-191, 2004.

KOVÁŘŮ H, KOVÁŘŮ F: Basis of neuroimmunomodulation. (in Czech) In: Základy neuroimmunomodulace. H KOVÁŘŮ, F KOVÁŘŮ (eds), Galén, Prague, 2005, pp 203-208.

KOVÁŘŮ H, FIŠEROVÁ A, LISÁ V, ŠPANOVÁ A, KOVÁŘU゚ F, VELEK J: Fluoxetine induced changes in C6 glioma cells and NK lymphocytes. In: Biologické základy psychických poruch. J SIKORA, Z FIŠAR et al. (eds), Galén Publ. Co, Prague, 1997, pp 108-112.

KOVÁŘŮ H, FIŠEROVÁ A, ŠPANOVÁ A, LISÁ V, FIŠAR Z, VELEK J: Antidepressants as neuroimmunomodulators at postreceptor level. J Neuroimmunol 90: 41, 1998.

KOVÁŘ Ů H, LISÁ V, FIŠAR Z, MALBOHAN I: Comparative analyses of antidepressant induced changes in G alpha subunit profiles. NeuroImmunomodulation 6: 460, 1999.

KOVÁŘU゚ H, FIŠEROVÁ A, KOVÁŘU゚ F, PACLT I, LISÁ V: Antidepressant or immunomodulator induced regulation of cell signalling in brain and immune system. Eur Neuropsychopharmacol 10 (Suppl 3): S269- S270, 2000. 
KOVÁŘŮ H, FIŠEROVÁ A, KOVÁŘŮ F, POSPÍŠIL M, LISÁ V: Modulation of heterotrimeric GTP-binding proteins in immune system and brain. Czech J Anim Sci 46: 62-67, 2001.

KUBOTA N, KIUCHI Y, NEMOTO M, OYAMADA H, OHNO M, FUNAHASHI H, SHIODA S, OGUCHI K: Regulation of serotonin transporter gene expression in human glial cells by growth factors. Eur J Pharmacol 417: 69-76, 2001.

LAMING PR, KIMELBERG H, ROBINSON S, SALM A, HAWRYLAK N, MULLER C, ROOTS B, NG K: Neuronal-glial interactions and behaviour. Neurosci Biobehav Rev 24: 295-340, 2000.

LEE HJ, CHA JH, HAM BJ, HAN CS, KIM YK, LEE SH, RYU SH, KANG RH, CHOI MJ, LEE MS: Association between a G-protein beta3 subunit gene polymorphism and the symptomatology and treatment responses of major depressive disorders. Pharmacogenomics J 4: 29-33, 2004.

LEONARD BE: Inflammation and depression: is there a causal connection with dementia? (in Czech) Psychiatrie 10: 172-178, 2006.

LUCASSEN PJ, HEINE VM, MULLER MB, VAN DER BEEK VM, WIEGANT VM, DE KLOET ER, JOELS M, FUCHS E, SWAAB DF, CZEH B: Stress, depression an hippocampal apoptosis. CNS Neurol Disord Drug Targets 5: 531-546, 2006.

MANEV R, UZ T, MANEV H: Fluoxetine increases the content of neurotrophic protein S100 $\beta$ in the rat hippocampus. Eur J Pharmacol 420: R1-R2, 2001.

MAREŠ V, GIORDANO PA, PELLICCIARI C, SCHERINI E, LISÁ V, BOTTONE G, BOTTIROLI G: Changes in cell cycle and chromatin distribution in C6 glioma cells treated by dibutyryl cyclic AMP. Cell Prolif 24: 569$577,1991$.

MCEWEN BS, MAGARINOS AM, REAGAN LP: Structural plasticity and tianeptine: cellular and molecular targets. Eur Psychiatry 17: 318-330, 2002.

MERCIER G, LENNON AM, RENOUF B, DESSOROUX A, RAMAUGE M, COURTIN F, PIERRE M: MAP kinase activation by fluoxetine and its relation to gene expression in cultured rat astrocytes. $J$ Mol Neurosci 24: 207216, 2004.

MIGUEL-HIDALGO JJ, RAJKOWSKA G: Comparison of prefrontal cell pathology between depression and alcohol dependence. J Psychiatr Res 37: 411-420, 2003.

MIYAZAKI I, ASANUMA M, DIAZ-CORRALES FJ, MIYOSHI K, OGAWA N: Direct evidence for expression of dopamine receptors in astrocytes from basal ganglia. Brain Res 1029: 120-123, 2004.

MIZUTA I, OHTA M, OHTA K, NISHIMURA M, MIZUTA E, HAYASHI K, KUNO S: Selegiline and desmethylselegiline stimulate NGF, BDNF, and GDNF synthesis in cultured mouse astrocytes. Biochem Biophys Res Commun 279: 751-755, 2000.

MOJCA-JURIC DM, MIKLIC S, CARMAN-KRZAN M: Monoaminergic neuronal activity up-regulates BDNF synthesis cultured neonatal rat astrocytes. Brain Res 1108: 54-62, 2006.

MÜLLER HV, JUNGHANS U, KAPPLER J: Astroglial neurotrophic and neurite-promoting factors. Pharmacol Ther 65: 1-18, 1995.

NAKAGAWA T, SCHWARTZ JP: Expression of neurotrophic factors and cytokines and their receptors on astrocytes in vivo. Adv Cell Mol Biol 31: 561-574, 2004.

NAKYAMA T, SOMOGI-SOGA T, INOUE N. Astrocyte-derived factors instruct differentiation of embryonic stem cells into neurons. Neurosci Res 46: 241-249, 2003.

NESTLER EJ, BARROT M, DILEONE RJ, EISCH AJ, GOLD SJ, MONTEGGIA LM: Neurobiology of depression. Neuron 34: 13-25, 2002.

NEUMEISTER A: Tryptophan depletion, serotonin and depression: where do we stand? Psychopharmacol Bull 37: 99$115,2003$.

NICHOLS NR, AGOLLEY D, ZIEBA M, BYE N: Glucocorticoid regulation glial responses during hippocampal neurodegeneration and regeneration. Brain Res Brain Res Rev 48: 287-301, 2005.

NOWAK G, TRULLAS R, LAYER RT, SKOLNICK P, PAUL IA: Adaptive changes in the $N$-methyl-D-aspartate receptor complex after chronic treatment with imipramine and 1-aminocyclopropanecarboxylic acid. J Pharmacol Exp Ther 265: 1380-1386, 1993. 
OHTA K, KUNO S, MIZUTA I, FUJINAMI A, MATSUI H, OHTA M: Effects of dopamine agonists bromocriptine, pergolide, cabergoline, and SKF-38393 on GDNF, NGF, and BDNF synthesis in cultured mouse astrocytes. Life Sci 73: 617-626, 2003.

O'KUSKY J, COLONNIER M: A laminar analysis of the number of neurons, glia, and synapses in the adult cortex (area 17) of adult macaque monkeys. J Comp Neurol 210: 278-290, 1982.

ÖNGÜR D, DREVETS WC, PRICE JL: Glial reduction in the subgenual prefrontal cortex in mood disorders. Proc Natl Acad Sci U.S.A. 95: 13290-13295, 1998.

PACHECO MA, STOCKMEIER C, MELTZER HY, OVERHOLSER JC, DILLEY GE, JOPE RS. Alterations in phosphoinositide signalling and G-protein levels in depressed suicide brain. Brain Res 723: 37-45, 1996.

PARPURA V, HAYDON PG: Physiological astrocytic calcium levels stimulate glutamate release to modulate adjacent neurons. Proc Natl Acad Sci USA 97: 8629-8634, 2000.

PAWLAK J, BRITO V, KÜPPERS E, BEYER C: Regulation of glutamate transporter GLAST and GLT-1 expression in astrocytes by estrogen. Brain Res Mol Brain Res 138: 1-7, 2005.

PORTER JT, MCCARTHY KD: Atrocytic neurotransmitter receptors in situ and in vivo. Prog Neurobiol 51: 439-455, 1997.

RAJKOWSKA G: Depression: what we can learn from postmortem studies. Neuroscientist 9: 273-284, 2003.

REYNAERT C, JANNE P, BOSLY A, STAQUET P, ZDANOWICZ N, VAUSE M, CHATELAIN B, LEJEUNE D: From health locus of control to immune control: internal locus of control has a buffering effect on natural killer cell activity decrease in major depression. Acta Psychiat Scand 92: 294-300, 1995.

RIDET JL, MALHOTRA SK, PRIVAT A, GAGE FH: Reactive astrocytes: cellular and molecular cues to biological function. Trends Neurosci 20: 570-577, 1997.

SAPENA R, MORIN D, ZINI R, MORIN C, TILLEMENT JP: Desipramine treatment differently down-regulates betaadrenoceptors of freshly isolated neurons and astrocytes. Eur J Pharmacol 300: 159-162, 1996.

SCHILDKRAUT JJ, MOONEY JJ: Toward a rapidly acting antidepressant: the normetanephrine and extraneuronal monoamine transporter (uptake 2) hypothesis. Am J Psychiatry 161: 909-911, 2004.

SEKOT M, GURLICH R, MARUNA P, PÁV M, UHLÍKOVÁ P: Evaulation of anxiety and depression of patients with malignant gastrointestinal cancer. (in Czech) Čes Slov Psychiatrie 5: 252-257, 2005.

SERI B, GARCIA-VERDUNO JM, MCEWEN BS, ALVAREZ-BUYLLA A: Astrocytes give rise to new neurons in the adult mammalian hippocampus. J Neurosci 21: 7153-7160, 2001.

SHARMA G, VIJAYARAGHAVAN S: Nicotinic cholinergic signaling in hippocampal astrocytes involves calciuminduced calcium release from intracellular stores. Proc Natl Acad Sci USA 98: 3631-3632, 2001.

SHELINE ZI: Neuroimaging studies of mood disorder effects on the brain. Biol Psychiatry 54: 338-352, 2003.

SHELINE ZI, MITTLER BL, MINTUN MA: The hippocampus and depression. Eur Psychiatry 17: 300-305, 2002.

SCHIEPERS OJ, WICHERS MC, MAES M: Cytokines and major depression. Prog Neuropsychopharmacol Biol Psychiatry 29: 637-638, 2005.

SLEZAK M, PFRIEGER FW: New roles for astrocytes: regulation of CNS synaptogenesis. Trends Neurosci 26: 531535, 2003.

SOFRONIEW MW: Reactive astrocytes in neuronal repair and protection. Neuroscientist 11: 400-407, 2005.

SPIEGEL AM: Defects in G protein coupled signal transduction in human disease. Annu Rev Physiol 58: 143-170, 1996.

STEFFENS DC, BYRUM CHE, MCQUOID DR, GREENBERG DL, PAYNE ME, BLITCHINGTON TF, MACFALL JR, KRISHNAN KRR: Hippocampal volume in geriatric depression. Biol Psychiatry 48: 301-309, 2000.

STONE EA, ARIANO MA: Are glial cells targets of the central noradrenergic system: a review of the evidence. Brain Res Brain Res Rev 14: 297-309, 1989.

STRUBING C, ROHWEDEL J, AHNERT-HILGER G, WIEDENMANN B, HESCHELER J, WOBUS AM: Development of $\mathrm{G}$ protein-mediated $\mathrm{Ca}^{2+}$ channel regulation in mouse embryonic stem cell-derived neurons. Eur J Neurosci 9: 824-832, 1997.

SYKOVÁ E: Glia and volume transmission during physiological and pathological states. J Neural Transm 112: $137-$ 147, 2005. 
ŠPANOVÁ A, KOVÁŘŮ H, LISÁ V, LUKÁŠOVÁ E, RITTICH B: Estimation of apoptosis in C6 glioma cells treated with antidepressants. Physiol Res 46: 161-164, 1997.

TACUMA K, BABA A, MATSUDA T: Astrocytic apoptosis: implications for neuroprotection. Prog Neurobiol 72: 111-127, 2004.

TAFET GE, BERNARDINI R: Psychoneuroendocrinological links between chronic stress and depression. Prog Neuropsychopharmacol Biol Psychiatry 27: 893- 903, 2003.

VEREKER E, O'DONNELL E, LYNCH A, KELLY A, NOLAN Y, LYNCH MA: Evidence that interleukin-1 $\beta$ and reactive oxygen species production play a pivotal role in stress induced impairment of LTP in the rat dentate gyrus. Eur J Neurosci 14: 1809-1819, 2001.

VERKHRATSKY A, STEINHÄUSER CH: Ion channels in glial cells. Brain Res Rev 32: 380-412, 2000.

VILLOSLADA P, GENAIN P: Role of nerve growth factor and other trophic factors in brain inflammation. Prog Brain Res 146: 403-414, 2004.

VITHINGHAM M, HEIM C, NEWPORT J, MILLER AH, ANDERSON E, BRONEN R, BRUMMER M, STAIB L, VERMETTEN E, CHARNEY DS, NEMEROFF CB, BREMNER JD: Childhood trauma associated with smaller hippocampal volume in women with major depression. Am J Psychiatr 159: 2072-2080, 2002.

WILSON CC, FABER KM, HARING JH: Serotonin regulates synaptic connections in the dentate molecular layer of adult rats via 5-HT $1 \mathrm{a}$ receptors: evidence for a glial mechanism. Brain Res 782: 235-239, 1998.

YOUNG LT, LI PP, KISH SJ, SIU KP, KAMBLE A, HORNYKIEWICZ O, WARSH JJ: Cerebral cortex Gs alpha protein levels and forskolin-stimulated cyclic AMP formation are increased in bipolar affective disorder. J Neurochem 61: 890-898, 1993.

ZELENAIA O, SCHLAG D, GOCHENAUER O, GANEL R, SONG W, BEELSEY JS, GRINSPAN JB, ROTHSTEIN JD, ROBINSON MB: Epidermal growth factor receptor agonists increase expression of glutamate transporter GLT-1 in astrocytes through pathways dependent on phosphatidylinositol 3-kinase and transcription factor NFkB. Mol Pharmacol 57: 667-678, 2000. 